\title{
Highest Pluvial-Lake Shorelines and Pleistocene Climate of the Western Great Basin
}

\author{
Marith Reheis \\ U.S. Geological Survey, MS-980, Federal Center, Box 25046, Denver, Colorado 80225
}

Received November 10, 1998

\begin{abstract}
Shoreline altitudes of several pluvial lakes in the western $\mathrm{G}$ reat Basin of North America record successively smaller lakes from the early to the late Pleistocene. This decrease in lake size indicates a long-term drying trend in the regional climate that is not seen in global marine oxygen-isotope records. At $+70 \mathrm{~m}$ above its late Pleistocene shoreline, Lake Lahontan in the early middle Pleistocene submerged some basins previously thought to have been isolated. Other basins known to contain records of older pluvial lakes that exceeded late Pleistocene levels include Columbus-Fish Lake (Lake C olumbus-R ennie), K obeh-D iamond (Lakes J onathan and D iamond), Newark, Long (Lake Hubbs), and Clover. Very high stands of some of these lakes probably triggered overflows of previously internally drained basins, adding to the size of Lake Lahontan. Simple calculations based on differences in lake area suggest that the highest levels of these pluvial lakes required a regional increase in effective moisture by a factor of 1.2 to 3 relative to late Pleistocene pluvial amounts (assuming that effective moisture is directly proportional to the hydrologic index, or lake area/tributary basin area). These previously unknown lake levels reflect significant changes in climate, tectonics, and (or) drainage-basin configurations, and could have facilitated migration of aquatic species in the $G$ reat Basin.
\end{abstract}

\section{INTRODUCTION}

Recent mapping in northern Nevada (Reheis and Morrison, 1997; Reheis et al., in press) has identified abundant sedimentologic and geomorphic evidence of lakes much older, and shorelines much higher, than several of the late Pleistocene lakes (Fig. 1: from west to east, Lakes Lahontan, ColumbusRennie, Jonathan [Kobeh Valley], Diamond, Newark, Hubbs [Long Valley], and Clover). During its well-studied late middle (Eetza; oxygen-isotope stage 6?) and late late Pleistocene (Sehoo; stage 2) highstands, Lake Lahontan reached maximum altitudes of about $1332 \mathrm{~m}$ and extended more than $350 \mathrm{~km}$, from the Nevada-Oregon border to beyond the southern end of Walker Lake (Fig. 1; e.g., Russell, 1885; Benson et al., 1990; Morrison, 1991). Many small, isolated lakes occupied other valleys in the western Great Basin (Mifflin and Wheat, 1979); their late Pleistocene highstands are not well dated. Little information was previously available on older pluvial lakes and their shoreline altitudes.
The focus of this paper is on the paleoclimatic implications and possible causes of the large, pre-late Pleistocene lakes. However, I briefly document here the evidence for, and ages of, these older pluvial lakes, which are discussed in detail in Reheis and Morrison (1997) and Reheis et al. (in press). The ages and altitudes of the old shorelines are estimated from shoreline features and sediments; numerical age control is obtained from tephra layers, magnetostratigraphy, and vertebrate fossils. The highest altitude of beach-gravel beds or lag on bedrock slopes is taken as a minimum shoreline altitude. Where beach morphology is discernible, relative preservation and relict soils permit relative-age and rough chronologic assignments by comparing soil properties to those of dated deposits in similar climatic regimes elsewhere in the western Great Basin (e.g., Reheis et al., 1995).

\section{HIGH SHORELINES, AGES, AND CORRELATIONS}

\section{High Shorelines in the Lahontan Basin}

Four primary and several subsidiary sites (Fig. 1) in the Walker Lake sub-basin document early and middle Pleistocene shorelines that are much higher than the Sehoo shoreline. Although active normal and strike-slip faults traverse much of the Walker Lake sub-basin, the southeastern part of the basin (the Thorne bar area, Fig. 1) is tectonically quiescent (Demsey, 1987; Stewart, 1988) and shorelines here are essentially undeformed (Reheis and Morrison, 1997).

Correlations based on ages, stratigraphic relations, and minimum shoreline altitudes among the four primary sites (Fig. 2; Reheis and Morrison, 1997) indicate six or seven lacustrine units whose shorelines exceeded that of the Sehoo lake. The three oldest units lie within the Matuyama Reversed Chron and thus are between about 2.6 and 0.78 myr (Cande and Kent, 1995); of these, the oldest is greater than 1.4 myr, the next is between about 1.4 and $1.1 \mathrm{myr}$, and the youngest begins about 1 myr and ends before 0.78 myr. The next younger unit contains the Bishop ash bed, if correctly identified on the basis of paleomagnetic data (Sarna-Wojcicki et al., 1991). The three youngest units probably postdate the 760,000-yr Bishop ash bed (Sarna-Wojcicki et al., 1991) and have shoreline altitudes at about $1400 \mathrm{~m}$ (oldest), $1370 \mathrm{~m}$, and $1350 \mathrm{~m}$ (youngest). 


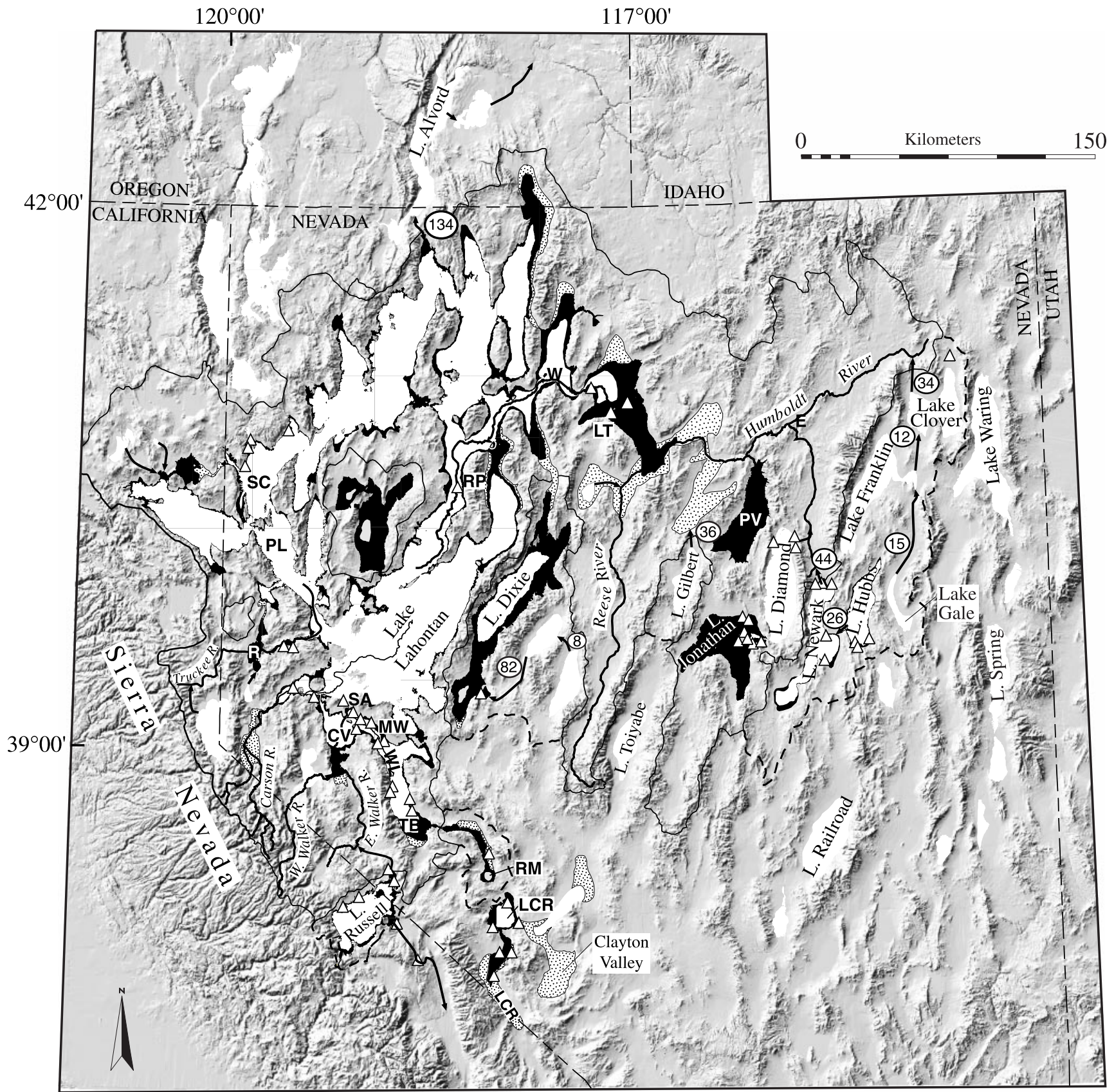

$\square$ Area of late Pleistocene lakes

(not all are shown)

Maximum known area of middle Pleistocene lakes

ㄱ. Possible additional area of middle Pleistocene lakes

$\triangle$ Pre-late Pleistocene lake deposit locality $\sim$ Late Pleistocene overflow

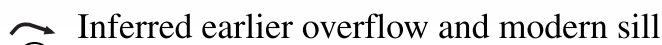

(8) height (m) above late Pleistocene shoreline

- Late Pleistocene boundary of Lahontan basin

- - Possible additional area of basin in middle Pleistocene

- Major drainages

FIG . 1. Regional map showing pluvial lakes of northern Nevada and vicinity. CV, Campbell Valley; E, Elko; LCR, Lake Columbus-Rennie (in Columbus Salt Marsh and extending into Fish Lake Valley); LM, Lone Mountain; LT, Lone Tree Hill; MW, McGee Wash; PV, Pine Valley; R, Reno; RM, Rhodes Salt Marsh; SA, Sunshine Amphitheater; SC, Smoke Creek Desert; TB, Thorne Bar; W, Winnemucca; WL, Walker Lake. 
At a previously unreported site on the Humboldt River, lacustrine deposits are abundantly exposed in the walls of the open-pit Lone Tree gold mine (Fig. 1; Reheis et al., in press). Beach gravel locally extends as high as about $1415 \mathrm{~m}$ on the south flank of Lone Tree Hill. Outcrops and drill core reveal the presence of four lake units separated by unconformities and paleosols. The oldest unit (in the core, not seen in outcrop) contains glass shards tentatively correlated with the 2.1-Ma Huckleberry Ridge ash (Izett, 1981). Reversely magnetized sediment of the next younger unit (exposed in pit walls) contains a Glass Mountain tephra and thus is about $1 \mathrm{myr}$, and the overlying unit contains the 760,000-yr Bishop ash. I correlate the youngest beach gravels, which unconformably overlie the unit containing Bishop ash, to those graded to the highest 1400-m shoreline in the Walker Lake sub-basin (Fig. 2). These deposits locally crop out higher at Lone Tree mine than Lahontan deposits of apparently similar age to the south, most likely because they are preserved on a horst (Lone Tree Hill) flanked on three sides by Quaternary normal faults with tens of meters of total displacement.

Beach gravels lagged on bedrock at unfaulted sites in the Smoke Creek Desert and east of Winnemucca (Fig. 1) indicate high stands at altitudes of about 1400 and $1370 \mathrm{~m}$ and possibly at about $1350 \mathrm{~m}$. These sites lack age control at present, but the correspondence of these altitudes with those of the three youngest shorelines in the Walker Lake sub-basin argues that they represent the same highstands of Lake Lahontan.

\section{High Shorelines in Other Lake Basins}

At least five other lake basins in Nevada contain evidence that middle Pleistocene lakes were much larger than late Pleistocene lakes (not all candidate lake basins have been visited by the author). New discoveries indicate at least three lake cycles higher and older than the late Pleistocene shoreline (altitude 1400 m; Mifflin and Wheat, 1979) of Lake Columbus-Rennie (Fig. 1). This area is essentially unaffected by Quaternary faulting. The highest preserved beach deposits at about 1452$1457 \mathrm{~m}$ in altitude reflect a lake that extended far south into Fish Lake Valley at about 760,000 yr (Reheis et al., 1993; Reheis and Morrison, 1997). Properties of relict soils on stable berm crests of the two lowest shorelines in the Columbus basin suggest ages of at least 50,000 yr and 20,000-10,000 yr, respectively (Reheis et al., 1995).

Two independent basins in east-central Nevada held Lake Hubbs and Lake Newark during the latest Pleistocene at shoreline altitudes of about 1902 and 1848 m, respectively. Three levels of beach gravels that are increasingly indistinct, hence older, with altitude are preserved above the late Pleistocene shorelines of both lakes (Fig. 1; two of these sites were first identified by Mifflin and Wheat, 1979). Properties of relict soils on the lowest three shorelines of Lake Newark suggest that the lowest shoreline is latest Pleistocene in age, the next higher is probably at least $100,000 \mathrm{yr}$, and the third is likely more than 200,000 yr (Reheis et al., 1999).
The large modern drainage basin of Lake Diamond (tributary to Lake Lahontan when overflowing) includes the ancient Lake Jonathan in Kobeh Valley. Davis (1987) inferred that lake sediments containing the 670,000-yr Rye Patch Dam ash bed (Fig. 2) represented an internally drained lake (here named Lake Jonathan, for its discoverer) that breached its sill and became tributary to Lake Diamond sometime after 670,000 yr. Paleomagnetic data and correlations of tephra from two older unconformity-bounded sets of lake sediments beneath those containing the Rye Patch Dam ash are tentatively interpreted to indicate that Lake Jonathan also had high stands at about 760,000 yr and at about 2.0 myr (Fig. 2; Reheis et al., in press). Thus, the record of Lake Jonathan is consistent with that of Lake Lahontan at Lone Tree Hill and in the Walker Lake sub-basin. Well preserved shoreline features in Diamond Valley also record high stands as much as $25 \mathrm{~m}$ above the late Pleistocene shoreline. Relict soils indicate that the highest of these is likely several hundred thousand years old (Mifflin and Wheat, 1979).

Newly discovered beach gravel crops out in large borrow pits along Interstate 80 in northern Independence Valley, part of the pluvial Lake Clover basin (Fig. 1; Mifflin and Wheat, 1979). This gravel is as much as $32 \mathrm{~m}$ above the late Pleistocene shoreline of Lake Clover and suggests the possibility of ancient overflow of the Lake Gale-Lake Franklin-Lake Clover chain of lakes into the Humboldt River at Wells, Nevada.

\section{Estimated Ages of High Shorelines}

The ages of gravels that mark the very high shorelines throughout the Lahontan basin and in the basin of Lake Jonathan can be estimated from underlying deposits. Deposits of Lake Jonathan, which contain 670,000-yr-old tephra and overlie an older lake unit containing Bishop ash, document an extreme high stand at about this time (Fig. 3). The unit that marks the 1400-m shoreline of Lake Lahontan overlies the $\sim 1$-myr lake unit at four sites, three in the Walker Lake sub-basin and one at Lone Tree Hill; it also overlies a unit containing 760,000-yr-old Bishop ash at Lone Tree Hill and possibly in the Thorne bar area (Fig. 2; Reheis and Morrison, 1997; Reheis et al., in press). At Sunshine Amphitheater, two layers of fan gravel and three argillic paleosols intervene between the $\sim 1$-myr lake unit and the highest beach gravel, an interval likely representing at least 150,000 yr (assuming $\sim 50,000 \mathrm{yr}$ are required to form an argillic horizon in the southern Great Basin; Reheis et al., 1995). All these relations and the very high lake level represented by these beach gravels throughout the Lahontan basin suggest a correlation to lacustrine deposits of the $\sim 700,000-600,000$-yr-old Rye Patch Alloformation of Lake Lahontan, which Morrison (1991) believes were deposited at least in part during oxygen-isotope stage 16, one of the largest deviations toward glacial (pluvial) conditions (Fig. 3).

In North America, the last two pluvial-lake cycles coincided with glaciations, though the highest shorelines of Great Basin 


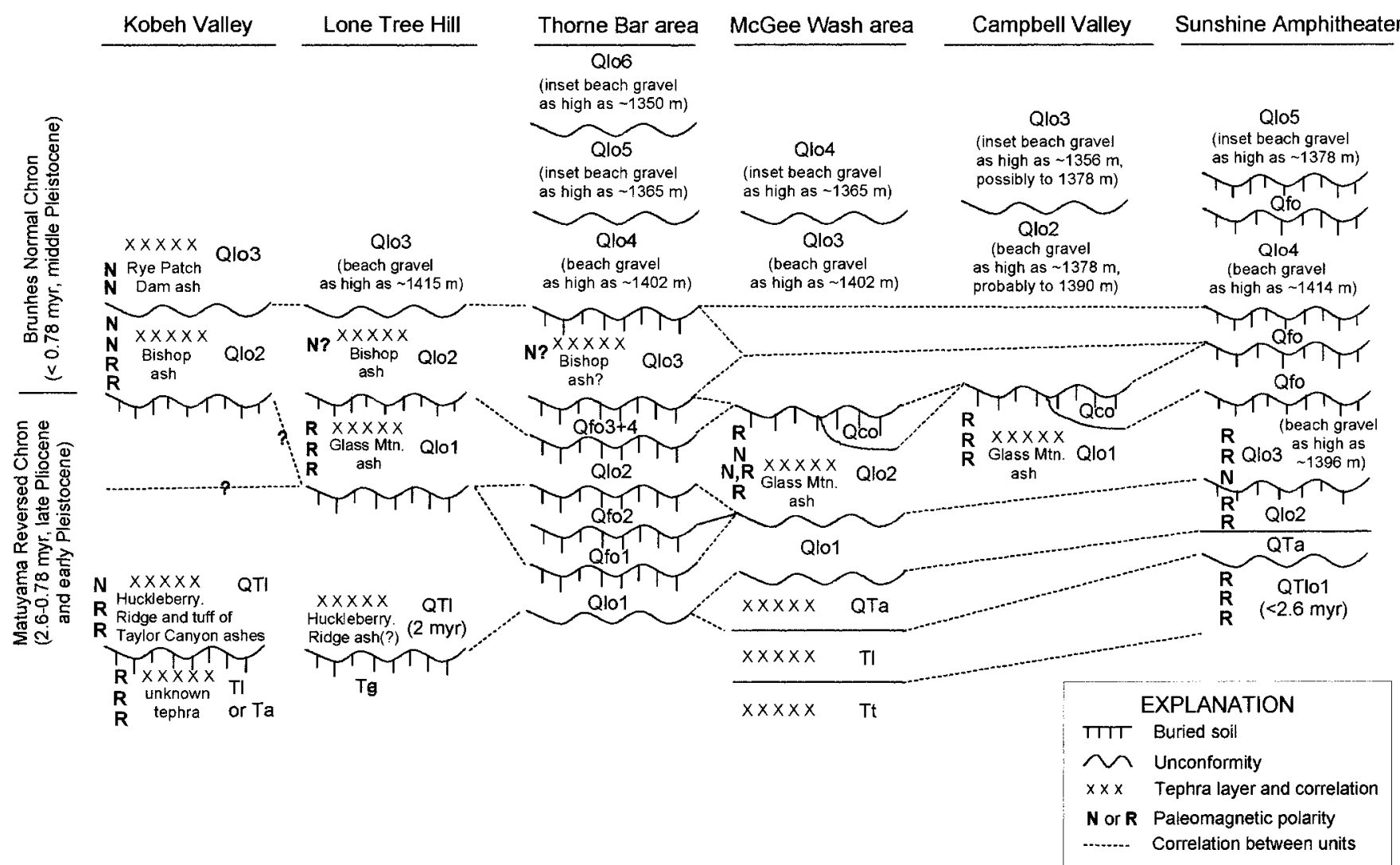

FIG. 2. Correlation of stratigraphic sections in Kobeh Valley (Lake Jonathan), at Lone Tree Hill (northern Lahontan basin), and in the Walker Lake basin. Multiple units (Qlo1, Qfo1, etc.) are numbered sequentially within each study area (from Reheis et al., in press). Q, Quaternary; T, Tertiary; lo, pre-late Wisconsin lake deposits; fo, pre-late Wisconsin fan deposits; a, alluvium; co, colluvium; t, tuff.

pluvial lakes somewhat postdated the maximum glacial advances of both continental ice sheets and montane glaciers during isotope stage 2 (e.g., Benson et al., 1990; Clark et al., 1995; Adams and Wesnousky, 1998). Major advances of ice sheets and montane glaciers in North America occurred just prior to deposition of the Lava Creek ash and just after deposition of the Bishop ash and (or) the beginning of the Brunhes Normal Chron (Richmond and Fullerton, 1986; Reheis et al., 1991), an interval that includes both oxygen-isotope stage 18 and stage 16 (Fig. 3). Because stage 18 apparently represents less-extensive glaciation worldwide than does stage 16 , I provisionally correlate deposits of the 1400-m highstand of Lake Lahontan and deposits of Lake Jonathan that contain the 670,000-yr Rye Patch Dam tephra with isotope stage 16, fully recognizing that more dating (of the shorelines as well as the tephra layers) is required to confirm this correlation.

I infer, on the basis of the rare occurrence and poor preservation of lag beach gravel on bedrock, that the highest shoreline deposits of Lakes Columbus-Rennie, Hubbs, and Newark are coeval with the 1400-m highstand of Lake Lahontan. From its degree of soil development, the highest shoreline of Lake Diamond (Mifflin and Wheat, 1979) may also have formed at this time. These correlations are bolstered by the preservation of lake sediments and very high beach gravels of this age (dated by ash beds) of Lake Jonathan (Fig. 2) and in Pine Valley (Smith and Ketner, 1976), not far northwest of Lakes Hubbs and Newark (Fig. 1).

Beach deposits of the $\sim 1370$-m and $\sim 1350$-m(?) shorelines of Lake Lahontan and of the two intermediate shorelines of Lakes Columbus-Rennie, Hubbs, and Newark, retain the forms of berms and shore platforms. Only relative-age information is available for these intermediate shoreline deposits. The relative preservation of berm morphology and properties of relict soils formed on the berms indicate that age increases with shoreline altitude (Reheis et al., in press; Adams and Wesnousky, 1996). In the Lahontan basin, these beach deposits are inset into older units at several localities in the Walker Lake sub-basin (Figs. 1 and 2); they represent units younger than that correlated to the Rye Patch Alloformation and as old or older than the high stand represented by the upper part of the Eetza Alloformation, thought to be equivalent to isotope stage 6 (Morrison, 1991).

Berms of the upper of the two intermediate shorelines have poorly preserved morphology but can still be detected on aerial photography. This group of deposits is represented by the 1370-m shoreline of Lake Lahontan, preserved in several localities, and by remnants in the other lake basins 12 to $30 \mathrm{~m}$ 


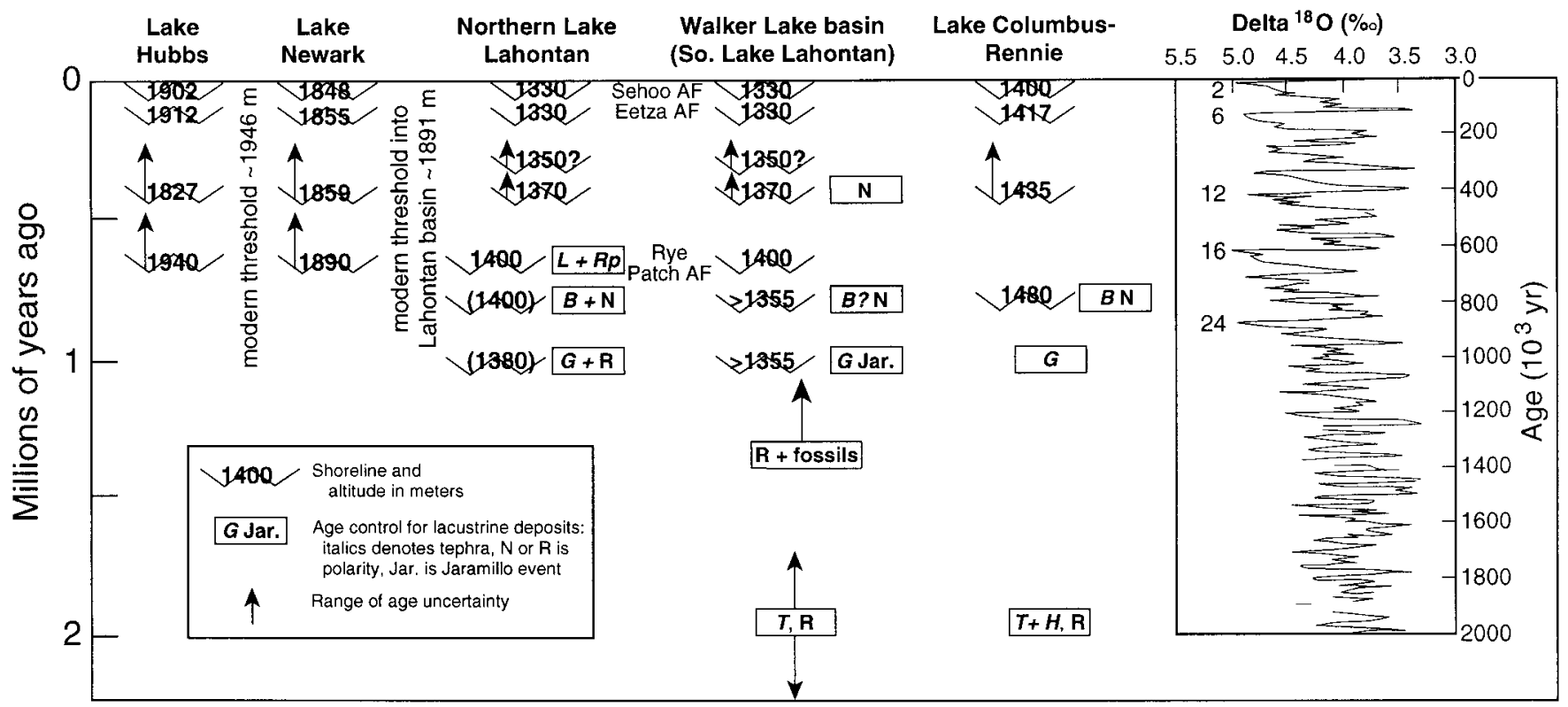

FIG. 3. Estimated shoreline altitudes and ages of pluvial lakes in northern Nevada, compared with the delta ${ }^{18} \mathrm{O}$ marine oxygen-isotope record (data from Imbrie et al., 1993). Data in the interval from 0 to 400,000 yr B.P. are from the SPECMAP stack; data below 400,000 yr B.P. are from ODP site 677 (Shackleton et al., 1990). Tephra abbreviations are: L, Lava Creek B (660,000 yr); Rp, Rye Patch Dam ash (670,000 yr); B, Bishop ash (760,000 yr); G, Glass Mountain G(?) ash ( $\sim 1$ myr); T, tuff of Taylor Canyon (several layers, $\sim 2$ myr); and H, Huckleberry Ridge ash (2.1 myr) (ages from Sarna-Wojcicki et al., 1991, and A. Sarna-Wojcicki, written communications, 1994-1997).

above their late Pleistocene highstands (Reheis et al., in press). Berms of the lower of the two intermediate shorelines are better preserved than the upper berms, but distinctly subdued compared to those of late Pleistocene age. Several lake basins contain numerous remnants of a lower intermediate shoreline 7 to $17 \mathrm{~m}$ above the late Pleistocene highstand; in the Lahontan basin, this lower level is only known thus far from one beach barrier in the Walker Lake sub-basin at about $1350 \mathrm{~m}$ (Fig. 2) and possibly by fluvial terrace gravels along the Carson and Humboldt Rivers. Properties of relict soils in the basins of Lakes Columbus-Rennie and Newark suggest an age greater than 50,000-100,000 yr (by comparison to dated soils in the southern Great Basin; Reheis et al., 1995, and in press), possibly correlative with the Eetza Alloformation of Lake Lahon$\tan$ (Morrison, 1991) and thus perhaps with isotope stage 6 (an intense glacial episode ending at about 130,000 yr). Assignment of the $1350-\mathrm{m}$ shoreline of Lake Lahontan to isotope stage 6 conflicts with Morrison's (1991) evidence that the highest Eetza shoreline is at about the same altitude as the 1332-m Sehoo shoreline of late Pleistocene age. However, soil data of Adams and Wesnousky (1996) suggests that Lahontan shorelines around the 1332-m level are all Sehoo in age. Recently published U-series ages of tufa from the Pyramid Lake area of Lake Lahontan show that the lake stood at intermediate levels (about $1207 \mathrm{~m}$ ) from about 400,000 to 170,000 yr B.P. (Szabo and Bush, 1996) and may have intermittently risen much higher, but the timing and altitude of the highstands is unknown.

\section{Correlation of Very High Shorelines in Nevada to Other Climate Records}

The early Pleistocene lake sediments of Lake Lahontan and Lake Jonathan represent several highstands whose ages are not easily related to the marine oxygen-isotope record (Fig. 3) and simulations of global ice volume (Imbrie and Imbrie, 1980), which show more rapid oscillations between glacial and interglacial conditions prior to about 0.9 myr. However, advances of the Laurentide ice sheet at about $2.2 \mathrm{myr}$ and $0.9 \mathrm{myr}$, of glaciers in the Yellowstone area at about $1.6 \mathrm{myr}$, of the Cordilleran ice sheet in the Puget Lowland three times during the Matuyama Chron (2.6-0.8 myr), of glaciers in the Sierra Nevada before about $0.8 \mathrm{myr}$ (all the foregoing summarized in Richmond and Fullerton, 1986), and of glaciers in British Columbia at about 1.1 myr (Spooner et al., 1995) record significant expansion of glacial ice that could be reflected by pluvial lakes in the Great Basin.

Other lakes in the western United States have early Pleistocene records that are similar to those of Lakes Lahontan and Jonathan. Tule Lake in northern California was deep and dilute between 1.4 and 1.2 myr (Bradbury, 1991), and Searles Lake in southern California was fresh and overflowing from 1.2 to 1.0 myr (Smith et al., 1983; Jannik et al., 1991). A lake was probably present in Fish Lake Valley (Lake Rennie; Reheis et al., 1993) and possibly in Death Valley (Knott et al., 1996) at about 1 myr. Links to pluvial lakes north of the Lahontan basin at 760,000 yr are problematic because the Bishop ash has not 
TABLE 1

Lake and Basin A reas and Modern Climate Data

\begin{tabular}{|c|c|c|c|c|c|c|}
\hline Pluvial lake & $\begin{array}{l}\text { MAP } \\
(\mathrm{cm})\end{array}$ & $\begin{array}{l}\text { MAT } \\
\left({ }^{\circ} \mathrm{C}\right)\end{array}$ & $\begin{array}{l}\text { Late Pleistocene } \\
\text { lake area }\left(\mathrm{km}^{2}\right)\end{array}$ & $\begin{array}{l}\text { Largest known } \\
\text { lake area }\left(\mathrm{km}^{2}\right)\end{array}$ & $\begin{array}{l}\text { Late Pleistocene } \\
\text { basin area }\left(\mathrm{km}^{2}\right)\end{array}$ & $\begin{array}{c}\text { Largest known } \\
\text { basin area }\left(\mathrm{km}^{2}\right)\end{array}$ \\
\hline Columbus-Rennie & 14 & 11.5 & 141 & $468-796$ & 3531 & 3531 \\
\hline Lahontan & & & 21,456 & $30,605-34,985$ & 114,693 & $119,511-130,900$ \\
\hline Newark & 33 & 7.6 & 817 & 986 & 3552 & 3552 \\
\hline Hubbs & 33 & 7.6 & 532 & 620 & 1724 & 1724 \\
\hline
\end{tabular}

Note. Lake areas from ARC/INFO measurements; basin areas from Mifflin and Wheat (1979). Mean annual precipitation (MAP) and temperature (MAT) from closest weather station.

been found north of Lone Tree Hill (Fig. 1). South of Lake Lahontan, the Bishop ash is contained within sediments of moderate to deep lakes of Lakes Columbus-Rennie (Fig. 1; Reheis et al., 1993), Clayton (Fig. 1; Reheis and Morrison, 1997), Owens (Smith et al., 1997), Searles (Jannik et al., 1991), and Manley (Knott et al., 1996). To the east in the Bonneville basin of Utah, however, the Bishop ash is contained within shallow-lake and fresh-water marsh deposits rather than deep-water sediment (Eardley et al., 1973; Oviatt et al., in press).

Three highstands of middle Pleistocene lakes recorded by beach gravels in several basins represent gradual decreases in lake size across northern Nevada since the early middle Pleistocene (Fig. 3). Such a consistent decrease in lake size is not apparent in other middle to late Pleistocene records from Lakes Owens, Searles (Smith et al., 1997; Jannik et al., 1991), and Bonneville (Oviatt et al., in press). These records depend largely on stratigraphic evidence from cores in pelagial (offshore) settings; thus, they are difficult to relate to the shorelines of this study (Currey, 1990). In addition, flow-through lakes like Owens and Searles do not sensitively record changes in runoff volume because they cannot change in "size." Nevertheless, the number of deep-lake cycles within the past 700,000 years interpreted from cores taken from Lakes Searles and Bonneville is consistent with the shorelines preserved in the basins of the present study. Lake Searles had major overflows to Lake Panamint between about 700,000 and 600,000 yr (two events), 440,000 and 350,000 yr (two events), 150,000 and $120,000 \mathrm{yr}$, and 24,000 and 10,000 yr (Jannik et al., 1991). The Burmester core from Lake Bonneville, previously thought to contain evidence for 17 deep-lake cycles during the Brunhes Normal Chron (Eardley et al., 1973), has been reinterpreted to indicate just four deep-lake cycles that are provisionally correlated with oxygen-isotope stages 16, 12, 6, and 2 (Oviatt et al., in press).

\section{PALEOCLIMATE RECONSTRUCTIONS}

Simple equations that relate lake and drainage-basin area to mean annual temperature, precipitation, runoff, and evapora- tion (Mifflin and Wheat, 1979) can be used to estimate the changes in climatic parameters required to produce the very large lakes in Nevada during the early middle Pleistocene (Table 1). Lake area, not volume or depth, is the gauge for response of closed-basin lakes to changes in the hydrologic balance (climate) (e.g., Mifflin and Wheat, 1979; Benson et al., 1990). In Tables 2 and 3, HI and $Z$ are equivalent hydrologic indices based on two different sets of parameters: $\mathrm{HI}=$ lake area $\div$ area of tributary basin; $Z=$ runoff from tributary basin $\div$ (lake evaporation - lake precipitation) (Mifflin and Wheat, 1979). Thus, HI is calculated from easily measured areas, whereas $Z$ is calculated from estimated quantities that are typically extrapolated using curves of runoff and precipitation versus altitude constructed using data from only a few sites, many of which are not located in the basins of interest. Until better data are available for runoff from these isolated, internally drained basins with large variations in topography, values of $Z$ in Table 3 should be considered only as guides to relative changes in hydrologic conditions. A third set of values in Table 2, normalized surface area, compares pluvial lake area to the area of historical lakes in a basin (Benson and Paillet, 1989).

At its highest known stand of $1400 \mathrm{~m}$, Lake Lahontan attained an area of about $30-35 \times 10^{3} \mathrm{~km}^{2}$ (the range is the difference between known and inferred possible lake areas, Fig. 1). The hydrologic index (HI) for the 1400-m lake level is about 1.5 times greater than $\mathrm{HI}$ for the 1332-m late Pleistocene highstand, identical to the difference between normalized lake areas at these levels (Table 2). The discrepancies between values of $\mathrm{HI}$ and normalized lake areas between the highest and the late Pleistocene levels of Lake Columbus-Rennie, close to the Sierra Nevada, are much larger ( $>2.5$ times) than those for Lake Lahontan; ${ }^{1}$ discrepancies between values of $\mathrm{HI}$ and normalized lake areas for Lakes Newark and Hubbs, $300 \mathrm{~km}$ east of the Sierra, are smaller ( $>1.2$ times). These relations suggest that the changes in climatic parameters required to achieve the

\footnotetext{
${ }^{1}$ Similar large discrepancies of HI values are calculated for nearby Lake Russell (Fig. 1; unpublished data).
} 
TABLE 2

Hydrologic Indices for Late Pleistocene and Maximum-Area Pluvial Lakes

\begin{tabular}{|c|c|c|c|c|c|c|}
\hline Pluvial lake & $\begin{array}{c}\mathrm{HI}^{a} \text { of late } \\
\text { Pleistocene lake }\end{array}$ & $\begin{array}{c}\mathrm{HI} \text { of } \\
\text { largest lake }\end{array}$ & $\begin{array}{c}\text { Increase in HI } \\
\text { (largest/late Pleistocene) }\end{array}$ & $\begin{array}{l}\text { Normalized area }^{b} \\
\text { of late Pleist. lake }\end{array}$ & $\begin{array}{l}\text { Normalized area } \\
\text { of largest lake }\end{array}$ & $\begin{array}{c}\text { Increase in } \\
\text { normalized area } \\
\text { (largest/late Pleist.) }\end{array}$ \\
\hline Columbus-Rennie* & 0.04 & $0.15-0.29$ & $2.5-7.0$ & 141.5 & 468.4 & $3.3-5.6$ \\
\hline Lahontan & 0.23 & $0.34-0.36$ & 1.5 & 8.9 & $12.6-14.5$ & $1.4-1.6$ \\
\hline Newark* & 0.30 & 0.38 & $1.3-1.4$ & 816.8 & 986.4 & 1.2 \\
\hline Hubbs* & 0.45 & 0.56 & $1.3-1.4$ & 532.2 & 620.0 & 1.2 \\
\hline
\end{tabular}

${ }^{a}$ HI, hydrologic index = area of lake/area of tributary basin (that is, basin area minus lake area) from Table 1 (Mifflin and Wheat, 1979).

${ }^{b}$ Normalized area $=$ area of pluvial lake/area of historical lake (Benson and Paillet, 1989).

* Basins of Lakes Columbus-Rennie, Newark, and Hubbs are dry; area of their historical lakes arbitrarily set as 1 for calculations.

highest stands of these pluvial lakes become smaller from west to east. However, it is possible that at their highest shoreline positions, Lakes Newark and Hubbs overflowed into a tributary of the Humboldt River (Fig. 1; Reheis et al., in press); thus, their lake-area values (HI) are minimum estimates of the increase in moisture required to reach these highest stands.

Calculations of the estimated hydrologic index $(Z)$ using different values for temperature, precipitation, runoff, and evaporation show that published paleoclimate parameters for the late Pleistocene in Nevada (first two columns of $Z$ values in Table 3) are insufficient to produce the highest shorelines of this study. Values of $Z$ derived from climate parameters based on physical models of Lake Lahontan (Hostetler and Benson, 1990) appear to match HI values for the highest stands of Lakes Newark and Hubbs (third column of $Z$ values in Table 3), but this model is specific to Lake Lahontan and is probably not appropriate to apply to other lake basins, especially those without runoff from the Sierra Nevada. Exploration of various combinations of climate parameters (Table 3) suggests that minimum changes required to produce the highest shorelines of Lakes Newark and Hubbs include (1) decreasing mean annual temperature by $5^{\circ} \mathrm{C}$ and increasing precipitation by $70 \%$, or (2) larger decreases in temperature and smaller increases in precipitation. If it is assumed that effective moisture is directly proportional to the hydrologic index, the data in Tables 2 and 3 suggest that to attain the highest level of Lake ColumbusRennie, the most southerly and arid basin in the present study, requires two to three times the present precipitation combined with a decrease of $8^{\circ} \mathrm{C}$. These parameters are similar to those of recent reconstructions using plant macrofossils which indicate that the low arid basins of southern Nevada were about $5-6^{\circ} \mathrm{C}$ colder and had more than twice as much precipitation during the last glacial maximum than at present (Thompson et al., in press). However, the presence of a relatively small shallow lake in the Columbus basin during the last pluvial period suggests that either (1) these recent reconstructions do not apply to the area of Lake Columbus-Rennie farther north, or (2) estimates of runoff used to calculate $Z$ in Table 3 are incorrect. Significant increases in effective moisture (based on HI values in Table 2, perhaps 30-50\% above late Pleistocene models suggested by Mifflin and Wheat, 1979; Spaulding et al., 1984; and Hostetler and Benson, 1990) are also required to produce the highest level of Lake Lahontan (Table 2).

TABLE 3

Estimated Climatic Parameters for Pluvial Lakes

\begin{tabular}{|c|c|c|c|c|c|c|c|}
\hline \multirow[b]{2}{*}{ Pluvial lake } & \multicolumn{7}{|c|}{$Z$ values $^{a}$ (compare to hydrologic index values $[\mathrm{HI}]$ of Table 2 ) } \\
\hline & $\begin{array}{l}-2.8^{\circ} \mathrm{C} \mathrm{MAT} \\
+70 \% \mathrm{MAP}^{b}\end{array}$ & $\begin{array}{l}-5^{\circ} \mathrm{C} \mathrm{MAT} \\
+40 \% \mathrm{MAP}^{c}\end{array}$ & $Z^{d}$ & $\begin{array}{l}-5^{\circ} \mathrm{C} \mathrm{MAT} \\
+70 \% \mathrm{MAP}\end{array}$ & $\begin{array}{l}-8^{\circ} \mathrm{C} \text { MAT } \\
+0 \% \mathrm{MAP}\end{array}$ & $\begin{array}{l}-8^{\circ} \mathrm{C} \text { MAT } \\
+40 \% \mathrm{MAP}\end{array}$ & $\begin{array}{l}-8^{\circ} \mathrm{C} \text { MAT, } \\
+70 \% \text { MAP }\end{array}$ \\
\hline Columbus-Rennie & 0.02 & 0.02 & 0.02 & 0.03 & 0.01 & 0.04 & 0.08 \\
\hline Newark & 0.33 & 0.28 & 0.88 & 0.55 & 0.19 & 0.78 & 2.11 \\
\hline Hubbs & 0.35 & 0.29 & 0.54 & 0.59 & 0.19 & 0.78 & 2.11 \\
\hline
\end{tabular}

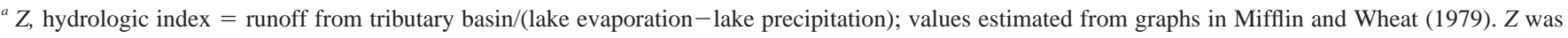
not calculated for Lake Lahontan because its drainage basin spans a very large area with great variability in climate parameters.

${ }^{b}$ Climatic parameters of Mifflin and Wheat (1979). MAT and MAP, mean annual temperature and precipitation.

${ }^{c}$ Climatic parameters of Spaulding et al. (1984).

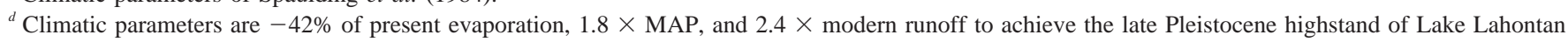
(Hostetler and Benson, 1990).
} 


\section{IMPLICATIONS OF VERY HIGH SHORELINES}

The Lahontan basin and several other lake basins in central and western Nevada contained pluvial lakes during the early to middle Pleistocene that were areally much larger, and had significantly higher shorelines, than the late Pleistocene lakes (Fig. 1). The descending bathtub-ring nature of the Nevada shoreline sequences suggests that younger pluvial periods became increasingly drier from the early middle to the late Pleistocene, a trend not apparent in most marine oxygenisotope records (Fig. 3). The relative importance of climate, tectonics, drainage changes, and water sources in causing the observed changes in pluvial lake levels in the western Great Basin is difficult to determine and probably has changed with time. Future work could test various combinations of these parameters using regional climate models to find the most plausible combinations. The possible parameters include:

(1) Changes in the position of the jet stream due to changing configurations of the Laurentide (and Cordilleran?) ice sheet could affect both precipitation and temperature in the western United States. Global circulation models show that the Laurentide ice sheet induces splitting of the jet stream; the movement of the two branches and their associated storm tracks appears to account for pluvial-lake fluctuations in the Basin and Range during the late Pleistocene (e.g., Thompson et al., 1993). Limited evidence suggests that temperatures may have been colder during earlier glaciations. Interpretations based on fluid inclusions in halite in the Death Valley core suggest that average temperatures could have been a few degrees colder during part of isotope stage 6 than during isotope stage 2 (Lowenstein et al., 1999). Relict colluvial deposits in southern Nevada suggest that winter temperatures in the southern Great Basin were at least $1^{\circ}-3^{\circ} \mathrm{C}$ colder in the early and middle Pleistocene than in the late Pleistocene (Whitney and Harrington, 1993). However, previous configurations (especially altitudes) of older ice sheets are too poorly known to estimate their effects on jet-stream position.

(2) Geologists have long thought that relative uplift of the Sierra Nevada since the late Pliocene, estimated to be about 1 $\mathrm{km}$ since 3 myr ago and $300 \mathrm{~m}$ since 800,000 years ago (Huber, 1981; Winograd et al., 1985), has produced an increasing rain shadow to the east through time. In contrast, recent studies have suggested that the range was elevated before the middle Miocene and has since been decreasing in average elevation (Small and Anderson, 1995; Wernicke et al., 1996). However, several lines of evidence indicate progressive warming and drying of at least the southern Great Basin during the past three million yr, consistent with an increasing rain-shadow effect. These include depletion in deuterium content and increasing $\delta^{18} \mathrm{O}$ content of ground water (Winograd et al., 1985, 1997), decline in water table (Winograd and Szabo, 1988; Hay et al., 1986), increase in salinity of lake deposits (Smith et al., 1983), and decrease in pluvial-lake size (this study). The apparent discrepancy may be resolved by Small and Anderson's (1995) model which suggests that uplift of the Sierra Nevada caused by isostatic response to erosion (rather than tectonic uplift) permits 30-200 m of uplift per million yr during the Quaternary in the maximum (as opposed to average) altitude of slowly eroding parts of the Sierran crest. In addition, there is strong evidence that the Transverse and Cascade Ranges to the south and north of the Sierra Nevada have increased in altitude since the Pliocene. Uplift of the western Cordillera relative to the western Basin and Range could help to explain the progressive decrease in lake levels since about 700,000 years ago.

(3) Regional-scale lithospheric subsidence may have decreased average altitudes in the northern Great Basin following uplift associated with emplacement at about 16 myr of the plume head of the Yellowstone hot spot, centering in northern Nevada near the Oregon-Idaho border (Pierce and Morgan, 1992; Parsons et al., 1994). This possible effect likely is not significant in the study area over the time span of the Quaternary, and seems contradicted by recent interpretations of fossil flora to suggest that elevations in western Nevada were much higher at about 15 myr (possibly due to emplacement of the plume head) but had decreased to about the same as the present by about 12 myr (Wolfe et al., 1997).

(4) More moisture may have crossed the Sierra Nevada in the early and early middle Pleistocene due to the presence of Lake Clyde, a tectonically dammed lake that filled the Great Valley of California (Sarna-Wojcicki, 1995). Water evaporated from this large $\left(30,000-50,000 \mathrm{~km}^{2}\right)$ lake could have recharged Pacific air masses that gave up moisture passing over the Coast Ranges of California. This additional water should have increased the snowpack on the Sierra Nevada but would have had less effect on ranges and pluvial lakes farther east. Lake Clyde overtopped its sill, rapidly incised its outlet, and drained shortly after 660,000 years ago (Sarna-Wojcicki, 1995). This effect helps explain the high lake levels of the early middle Pleistocene and some earlier periods but does not account for the highstands of younger pluvial lakes.

(5) Drainage changes have altered the size of the Lahontan drainage basin through time. For example, Lake Russell probably discharged into the Walker River in the late Pliocene or early Pleistocene (Fig. 1; Reheis and Morrison, 1997). Other lake basins now tributary to Lake Lahontan were previously isolated; Pine Valley (PV, Fig. 1; Smith and Ketner, 1976) and Lake Jonathan were internally drained until sometime after about 660,000 yr ago. The highest shorelines of Lakes Hubbs and Newark are very close to modern sill levels between these two basins and between the Newark and Lahontan basins (Fig. 3 ), permitting the possibility that these lakes were temporarily tributary to Lake Lahontan during this old (isotope stage 16?) lake cycle. In addition, other pluvial lakes in east-central Nevada that were isolated during the late Pleistocene, such as Lakes Gilbert, Gale, Franklin, and Clover (Fig. 1; Mifflin and Wheat, 1979), could have discharged into the Lahontan basin with rises of about 10-40 $\mathrm{m}$ above their late Pleistocene levels 
(estimated from modern topography and not accounting for changes due to faulting and sedimentation). These four basins presently contain relict fish populations that indicate former drainage connections with the Lahontan basin via the Humboldt River (Hubbs et al., 1974). Other overflows and basin connections are also possible (Fig. 1). Thus, these high lake stands may prove key to understanding the distribution of native populations of fish and other aquatic species in the Great Basin (e.g., Hubbs and Miller, 1948; Minckley et al., 1986; Hershler and Sada, in press).

\section{ACKNOWLEDGMENTS}

I thank the following USGS personnel: A. Sarna-Wojcicki for tephrochronologic analyses, C. Repenning and J. Honey for vertebrate fossil identifications, and R. Reynolds and J. Rosenbaum for assistance with paleomagnetic analyses. J. Yount and P. Glancy assisted in initial descriptions of deposits in the Lone Tree Mine. J. Rademaekers, M. O'Donnell, and G. Garcia produced Figure 1 and the lake areas in Table 1 using ARC/INFO. This paper benefited from discussions with R. Thompson and R. Forester and from thoughtful comments by J. Oviatt, J. P. Bradbury, A. Fryer, G. Smith, and several other anonymous reviewers.

\section{REFERENCES}

Adams, K. D., and Wesnousky, S. G. (1996). Soil development, spatial variability and the age of the highest late Pleistocene Lake Lahontan shorelines, western Nevada and northeastern California, Appendix 2. In "Quaternary History, Isostatic Rebound and Active Faulting in the Lake Lahontan Basin, Nevada and California: Friends of the Pleistocene, Pacific Cell, 1996 Fall Field Trip" (K. D. Adams and S. A. Fontaine, Eds.), Privately published, Reno, Nevada.

Adams, K. D., and Wesnousky, S. G. (1998). Shoreline processes and the age of the Lake Lahontan highstand in the Jessup embayment, Nevada. Geological Society of America Bulletin 110, 1318-1332.

Benson, L. V., and Paillet, F. L. (1989). The use of total lake-surface area as an indicator of climatic change: Examples from the Lahontan basin. Quaternary Research 32, 262-275.

Benson, L. V., Currey, D. R., Dorn, R. I., Lajoie, K. R., Oviatt, C. G., Robinson, S. W., Smith, G. I., and Stine, S. (1990). Chronology of expansion and contraction of four Great Basin lake systems during the past 35,000 years. Palaeogeography, Palaeoclimatology, Palaeocology 78, 241-286.

Bradbury, J. P. (1991). The late Cenozoic diatom stratigraphy and paleolimnology of Tule Lake, Siskiyou Co. California. Journal of Paleolimnology 6, 205-255.

Cande, S. C., and Kent, D. V. (1995). Revised calibration of the geomagnetic polarity timescale for the Late Cretaceous and Cenozoic. Journal of Geophysical Research 100, no. B4, 6093-6095.

Clark, D. H., Bierman, P. R., and Larsen, P. (1995). Improving in situ cosmogenic chronometers. Quaternary Research 44, 367-377.

Currey, D. R. (1990). Quaternary palaeolakes in the evolution of semidesert basins, with special emphasis on Lake Bonneville and the Great Basin, U.S.A. Palaeogeography, Palaeoclimatology, Palaeoecology 76, 189-214.

Davis, J. O. (1987). Tephrochronology of middle Pleistocene lake sediments in Kobeh Valley, Nevada: Implications for neotectonics and drainage history of the central Great Basin. Geological Society of America Abstracts with Programs 19, no. 6, 370.

Demsey, K. (1987). "Holocene Faulting and Tectonic Geomorphology along the Wassuk Range, West-Central Nevada." Unpublished M.S. thesis, University of Arizona, Tucson.
Eardley, A. J., Shuey, R. T., Gvosdetsky, V., Nash, W. P., Picard, M. D., Grey, D. C., and Kukla, G. J. (1973). Lake cycles in the Bonneville Basin, Utah. Geological Society of America Bulletin 84, 211-216.

Hay, R. L., Pexton, R. E., Teague, T. T., and Kyser, T. K. (1986). Springrelated carbonate rocks, $\mathrm{Mg}$ clays, and associated minerals in Pliocene deposits of the Amargosa Desert, Nevada and California. Geological Society of America Bulletin 97, 1488-1503.

Hershler, R., and Sada, D. W. (in press). Biogeography of Great Basin freshwater snails of the genus Pyrgulopsis. In "Great Basin Aquatic Systems History" (D. Currey, R. Hershler, and D. Madsen, Eds.), Smithsonian Institution, Washington, DC.

Hostetler, S., and Benson, L. V. (1990). Paleoclimatic implications of the high stand of Lake Lahontan derived from models of evaporation and lake level. Climate Dynamics 4, 207-217.

Hubbs, C. L., and Miller, R. R. (1948). The Great Basin. II. The zoological evidence. University of Utah Bulletin 38, 17-166.

Hubbs, C. L., Miller, R. R., and Hubbs, L. C. (1974). Hydrographic history and relict fishes of the north-central Great Basin. California Academy of Sciences Memoir 7, 259 p.

Huber, N. K. (1981). Amount and timing of late Cenozoic uplift and tilt of the Sierra Nevada, California-Evidence from the upper San Joaquin River basin. U.S. Geological Survey Professional Paper 1197, 28 p.

Imbrie, J., and Imbrie, J. Z. (1980). Modeling the climatic response to orbital variations. Science 207, 943-953.

Imbrie, J., Berger, A., Boyle, E. A., Clemens, S. C., Duffy, A., Howard, W. R., Kukla, G., Kutzbach, J., Martinson, D. G., McIntyre, A., Mix, A. C., Molfino, B., Morley, J. J., Peterson, L. C., Pisias, N. G., Prell, W. L., Raymo, M. E., Shackleton, N. J., and Toggweiler, J. R. (1993). SPECMAP Archive \#4. IGBP PAGES/World Data Center-A, Data Contribution Series 93-031.

Izett, G. A. (1981). Volcanic ash beds; recorders of upper Cenozoic silicic pyroclastic volcanism in the Western United States. Journal of Geophysical Research 86 (B11), 10,200-10,222.

Jannik, N. O., Phillips, F. M., Smith, G. I., and Elmore, D. (1991). A ${ }^{36} \mathrm{Cl}$ chronology of lacustrine sedimentation in the Pleistocene Owens River system. Geological Society of America Bulletin 103, 1146-1159.

Knott, J. R., Sarna-Wojcicki, A. M., Meyer, C. E., Tinsley, J. C. III, Wan, E., and Wells, S. G. (1996). Late Neogene stratigraphy of the Black Mountains piedmont, eastern California: Implications for the geomorphic and neotectonic evolution of Death Valley. Geological Society of America Abstracts with Programs 28, no. 5, 82.

Lowenstein, T. K., Li, J., Brown, C., Roberts, S. M., Ku, The-L., Luo, S., and Yang, W. (1999). 200 k.y. paleoclimate record from Death Valley salt core. Geology 27, 3-6.

Mifflin, M. D., and Wheat, M. M. (1979). Pluvial lakes and estimated pluvial climates of Nevada. Nevada Bureau of Mines and Geology Bulletin 94, 57 p.

Minckley, W. L., Hendrickson, D. A., and Bond, C. E. (1986). Geography of western North American freshwater fishes: Description and relationships to intracontinental tectonism. In "Zoogeography of North American Freshwater Fishes" (C. H. Hocutt and E. O. Wiley, Eds.), pp. 519-613. Wiley, New York.

Morrison, R. B. (1991). Quaternary stratigraphic, hydrologic, and climatic history of the Great Basin, with emphasis on Lakes Lahontan, Bonneville, and Tecopa. In "Quaternary Nonglacial Geology: Conterminous U.S." (R. B. Morrison, Ed.), The Geology of North America, v. K-2, pp. 283-320. Geological Society of America, Boulder.

Oviatt, C. G., Thompson, R. S., Kaufman, D. S., Bright, J., and Forester, R. M. (in press). Reinterpretation of the Burmester core, Bonneville basin, Utah. Quaternary Research.

Parsons, T., Thompson, G. A., and Sleep, N. H. (1994). Mantle plume 
influence on the Neogene uplift and extension of the U.S. western Cordillera. Geology 22, 83-86.

Pierce, K. L., and Morgan, L. A. (1992). The track of the Yellowstone hot spot: Volcanism, faulting, and uplift. In "Regional Geology of Eastern Idaho and Western Wyoming" (P. K. Link, M. A. Kuntz, and L. B. Platt, Eds.), pp. 1-53. Geological Society of America Memoir 179.

Reheis, M. C., and Morrison, R. B. (1997). High, old pluvial lakes of western Nevada. In "Proterozoic to recent stratigraphy, tectonics, and volcanology, Utah, Nevada, southern Idaho and central Mexico" (P. K. Link and B. J. Kowallis, Eds.), v. 42, pt. 1, pp. 459-492. Brigham Young University Geology Studies, Provo.

Reheis, M. C., Palmquist, R. C., Agard, S. S., Jaworowski, C., Mears, B., Jr., Madole, R. F., Nelson, A. R., and Osborn, G. D. (1991). Quaternary history of some southern and central Rocky Mountain basins. In "Quaternary Nonglacial Geology: Conterminous US" (R. B. Morrison, Ed.), The Geology of North America, v. K-2, pp. 407-440. Geological Society of America, Boulder.

Reheis, M. C., Slate, J. L., Sarna-Wojcicki, A. M., and Meyer, C. E. (1993). A late Pliocene to middle Pleistocene pluvial lake in Fish Lake Valley, Nevada and California. Geological Society of America Bulletin 105, 953-967.

Reheis, M. C., Slate, J. L., and Sawyer, T. L. (1995). Geologic map of late Cenozoic deposits and faults in parts of the Mt. Barcroft, Piper Peak, and Soldier Pass 15' quadrangles, Esmeralda County, Nevada, and Mono County, California. U.S. Geological Survey Miscellaneous Investigations Series Map I-2264, scale 1:24,000.

Reheis, M. C., Sarna-Wojcicki, A. M., Reynolds, R. L., Repenning, C. A., and Mifflin, M. D. (in press). Pliocene to middle Pleistocene lakes in the western Great Basin: Ages and connections. In "Great Basin Aquatic Systems History" (D. Currey, R. Hershler, and D. Madsen, Eds.), Smithsonian Institution, Washington, D.C.

Richmond, G. M., and Fullerton, D. S. (1986). Summation of Quaternary glaciations in the United States of America. In "Quaternary Glaciations in the United States of America" (G. M. Richmond and D. S. Fullerton, Eds.). Quaternary Science Reviews 5 (Quaternary Glaciations in the Northern Hemisphere), 183-196.

Russell, I. C. (1885). Geological history of Lake Lahontan, a Quaternary lake of northwestern Nevada. U.S. Geological Survey Monograph 11, 288.

Sarna-Wojcicki, A. M. (1995). Age, areal extent, and paleoclimatic effects of "Lake Clyde", a mid-Pleistocene lake that formed the Corcoran Clay, Great Valley, California. Abstracts for Glacial History of the Sierra Nevada, California-a symposium in memorial to Clyde Wahrhaftig, Sept. 20-22, 10 pp. White Mountain Research Station, Bishop, California.

Sarna-Wojcicki, A. M., Lajoie, K. R., Meyer, C. E., Adam, D. P., and Rieck, H. J. (1991). Tephrochronologic correlation of upper Neogene sediments along the Pacific margin, conterminous United States. In "Quaternary Nonglacial Geology: Conterminous US" (R. B. Morrison, Ed.), The Geology of North America, v. K-2, pp. 117-140. Geological Society of America, Boulder.

Small, E. E., and Anderson, R. S. (1995). Geomorphically driven late Cenozoic rock uplift in the Sierra Nevada, California. Science 270, 277-280.

Smith, G. I., Barczak, V. J., Moulton, G., and Liddicoat, J. C. (1983). Core KM-3, a surface-to-bedrock record of late Cenozoic sedimentation in Searles Valley, California. U.S. Geological Survey Professional Paper 1256, 24 p.
Smith, G. I., Bischoff, J. L., and Bradbury, J. P. (1997). Synthesis of the paleoclimatic record from Owens Lake core OL-92. In "An 800,000-year paleoclimatic record from core OL-92, Owens Lake, southeast California" (G. I. Smith and J. L. Bischoff, Eds.), pp. 143-160. Geological Society of America Special Paper 317.

Smith, J. F. J., and Ketner, K. B. (1976). Stratigraphy of post-Paleozoic rocks and summary of resources in the Carlin-Pinon Range area, Nevada. U.S. Geological Survey Professional Paper 867-B, 48.

Spaulding, W. G., Robinson, S. W., and Paillet, F. L. (1984). Preliminary assessment of climatic change during late Wisconsin time, southern Great Basin and vicinity, Arizona, California, and Nevada. U.S. Geological Survey Water Resource Investigations Report 84-4328.

Spooner, I. S., Osborn, G. D., Barendregt, R. W., and Irving, E. (1995). A record of early Pleistocene glaciation on the Mount Edziza Plateau, northwestern British Columbia. Canadian Journal of Earth Sciences 32, 20462056.

Stewart, J. H. (1988). Tectonics of the Walker Lane belt, western Great Basin: Mesozoic and Cenozoic deformation in a zone of shear. In "Metamorphism and Crustal Evolution of the Western United States" (W. G. Ernst, Ed.), pp. 683-713. Prentice Hall, Englewood Cliffs, NJ.

Szabo, B. J., and Bush, C. A. (1996). Uranium-series dating of carbonate (tufa) deposits associated with Quaternary fluctuations of Pyramid Lake, Nevada. Quaternary Research 45, 271-281.

Thompson, R. S., Anderson, K. H., and Bartlein, P. J. (in press). Quantitative paleoclimatic reconstructions from late Pleistocene plant macrofossils of the Yucca Mountain region. U.S. Geological Survey Open-file Report.

Thompson, R. S., Whitlock, C., Bartlein, P. J., Harrison, S. P., and Spaulding, W. G. (1993). Climatic changes in the western United States since 18,000 yr B.P. In "Global Climates Since the Last Glacial Maximum" (H. E. Wright Jr., J. E. Kutzbach, T. Webb III, W. F. Ruddiman, F. A. Street-Perrott, and P. J. Bartlein, Eds.), pp. 468-513. University of Minnesota Press, Minneapolis.

Wernicke, B., Clayton, R., Ducea, M., Jones, C. H., Park, S., Ruppert, S., Saleeby, J., Snow, J. K., Squires, L., Fliedner, M., Jiracek, G., Keller, R., Klemperer, S., Luetgert, J., Malin, P., Miller, K., Mooney, W., Oliver, H., and Phinney, R. (1996). Origin of high mountains in the continents: The southern Sierra Nevada. Science 271, 190-193.

Winograd, I. J., and Szabo, B. J. (1988). Water-table decline in the southcentral Great Basin during the Quaternary: Implications for toxic waste disposal. In "Geologic and hydrologic investigations of a potential nuclear waste disposal site at Yucca Mountain, southern Nevada" (M. D. Carr and J. C. Yount, Eds.), pp. 147-152. U.S. Geological Survey Bulletin 1790.

Winograd, I. J., Szabo, B. J., Coplen, T. B., Riggs, A. C., and Kolesar, P. T. (1985). Two-million-year record of deuterium depletion in Great Basin ground waters. Science 227, 519-522.

Winograd, I. J., Landwehr, J. M., Ludwig, K. R., Coplen, T. B., and Riggs, A. C. (1997). Duration and structure of the past four interglaciations. Quaternary Research 48, 141-154.

Wolfe, J. A., Schorn, H. E., Forest, C. E., and Molnar, P. (1997). Paleobotanical evidence for high altitudes in Nevada during the Miocene. Science 276, 1672-1675. 